\title{
Effect of Fly Ash on Crop Coverage around coal- fired Thermal Power Plant in Rural India
}

\author{
Subhas Adak ${ }^{1}$, Kalyan Adhikari ${ }^{2}$, Koushik Brahmachari $^{3}$ \\ ${ }^{1,2}$ Department of Earth and Environmental Studies, National Institute of Technology, Durgapur, India \\ ${ }^{3}$ Department of Agronomy, Bidhan Chandra Krishi Viswavidyalay, Mohanpur, India
}

\begin{abstract}
Fly ash coming out from Kolaghat thermal power plant, West Bengal, India affects the crop coverage in the surrounding area $(<4 \mathrm{~km})$. The arable areas under different crops, rice ( $-4.87 \%)$, wheat ( $-67.6 \%)$, maize ($10 \%)$, mustard ( $-29.1 \%)$, sesame ( $-8.33 \%)$, jute ( $-10 \%)$, vegetables $(-14.8 \%)$, flowers $(-8.06 \%)$ and pulses ($32.4 \%)$ have been gradually losing due to fly ash $(<4 \mathrm{~km})$ except spices ( $4.76 \%)$ during last four years (20112015) whereas the area beyond $4 \mathrm{~km}$ has gained the space for more cultivation ( overall 1.7\%) except rice( $0.09 \%)$ and jute( $-1.41 \%)$ due to low price and demand. The nearer circles, Kola-I,Kola-II, Gopalnagar, Pulsita, Sagarbarh and Amalhanda has lost cultivable land by $0.95 \%$ to $2.86 \%$ recording overall change $67.64 \%$ to $65.52 \%$ while the rest circles shows the change from $76.27 \%$ to $75.12 \%$. The average cropping system ( $<4 \mathrm{~km})$ has dropped down from $181.3 \%$ to $166.8 \%$ whereas it has shifted from $195.1 \%$ to $183.6 \%$ in the outer side (>4km). As the consequence of fly ash, agricultural land $(<4 \mathrm{~km})$ has been converted to non-agricultural one by $1.096 \%$ (Sagarbarh) to $5.184 \%$ (Kola-II) contrasting the transformation to non-arable in the area $(>4 \mathrm{~km})$ from $0.537 \%$ (Siddha-I) to $2.383 \%$ (Baishnabchak). Sitespecific evaluation and recommendation as well as organic farming and precision agriculture should be adopted to abate the impact of coal-burned thermal power plant for agricultural sustainability in rural India.
\end{abstract}

Keywords-Fly ash, Crop Coverage, Cropping Intensity, Land use Pattern.

\section{INTRODUCTION}

Throughout the world, the most demanded from of energy is electricity. Electricity is the driving force of the modern civilization. Out of total produced electricity, Coal fired thermal power plant contributes $41 \%$ of electricity in the world

(www.worldcoal.org/coal/uses-coal/coalelectricity) and $61.32 \%$ in India ("All India Installed Capacity of Utility Power Stations" (PDF) Retrieved 9 September 2016). At present (2016) 132 number of coal fired thermal power plants have been installed in different states all over India. In West Bengal 13 coal burned thermal power plants have been established sharing83.67\% out of 10068.40MW ( "All India Installed Capacity of Utility Power Stations" (PDF) Retrieved 9 September 2016). Kolaghat thermal power plant (KTPP) is one of them. It was installed in the year 1984 with initial capacity of $210 \mathrm{MW}$. Gradually its electricity generating capability had been raised to $1260 \mathrm{MW}$ with six units in the year 1994. The Kolaghat Thermal Power Plant is situated at $22^{\circ} 28^{\prime} 16^{\prime \prime} \mathrm{N}$ and $87^{\circ} 52^{\prime} 12^{\prime \prime} \mathrm{E}$ on the right bank of the Rupnarayan river in the district of Purba Medinipur, West Bengal. The present electricity generating capacity of KTPP is $1260 \mathrm{MW}$. The plant produces 7500-8000 metric ton of ash every day by consuming a total of 18000 ton of coal. The Power Plant emits considerable amount of fly ash. For usual disposal of ash one acre of land is required for one megawatt electricity produced in the whole life of the plant that is about 30 years (Adak, et al., 2016; Dasgupta, A. and Paul, S., 2011). So the KTPP requires 1260 acre of land for the disposal of ash generated in its life time. At present the plant has only 325 acre of land located 4-5 km away from it. The fly ash which is coming out of the chimneys generally subsides in the surrounding areas generally 3 $4 \mathrm{~km}$ away (Adak, et al., 2016; Dasgupta, A. and Paul, S., 2011). In order to cope up with the pressure of population, every bit of available land has been brought under various types of uses, which put high pressure on the land (Joshi and Nagare, 2009). Kolaghat Block is the most affected area of coal-fired thermal plant (Adak, et $a l$, 2016; Dasgupta, A. and Paul, S., 2011). It is covering geographical area of 15480.51 . It is divided into thirteen gram- panchayats or circles namely Kola-I ,Kola-II, Gopalnagar, Baishnavchak, Khanyadihi , Pulsita ,Sagarbarh , Amalhanda, Deriachak , Bhogpur, Siddha-I , Siddha-II and Brindabanchak. Some circles Kola-I, Kola-II, Gopalnagar, Pulsita, Sagarbarh, Amalhanda are situated within radius $(4 \mathrm{~km})$ of danger zones of thermal power plant. Agriculture is the prime source of livelihood of the block. Socio-economic conditions of the region mainly depend on agriculture. The agricultural areas are decreasing with the passage of time after the installment of thermal power plant at Kolaghat (Adak, et al,, 2016; Dasgupta, A. and Paul, S., 2011). According to the 
Summary report of the study on "Post-Clearance Environmental Impacts and Cost-benefit Analysis of Power Generation in India" Conducted by National Environmental Engineering Research Institute in February, 2006, it was stated that land was losing due to change in natural soil properties affected by coal based plants at Ramagundam in Telangana, Chandrapur in Maharashtra and Gandhinagar in the state of Gujarat, India. According to Garg, J.K. (1990) deposition of fly ash and coal dust has affected about $844.90 \mathrm{sq}$. $\mathrm{km}$ area as per December 1988 imagery in Talcher in the state of Odisha. Due to mining activities and thermal power generation, forest area was decreased by $34 \%$ during the period 1975 to 1989 . The area under fly ash deposition increased from 25 sq. km in 1979 to 117 sq. km in 1987 due to Talcher Thermal Power Station (TTPS) in the state of Odisha. Avirneni, S. and Bandlamudi, D. (2013) reported that fly ash affected the land use, soil and water. Kumar, et al., (2013) also reported that the thermal power plant had serious impacts on land, soil and air. Y Y Dudhapachare (2012) observed during investigation of upcoming thermal power plant in Chandrapur district of Maharashtra that the basic requirement for establishing the thermal power plant was huge land for plant area, ash Dump Lake, residential colony and water reservoir. This was direct impact on the land, but beyond this there was much invisible impact and land use in associate with the thermal power. According to Chitade, et al., (2010) from the analysis of land use land cover classification of multitemporal satellite data it had been observed that there are enormous changes especially in vegetation and agricultural area. Almost dense vegetation had been converted either into mine land or artificially created mountains of mine overburden in Chandrapur thermal power plant of Maharashtra. Shamshad, et al., (2012) also observed that fly ash affected the general aesthetics of environment in terms of land use, air, soil and water. According to Salesh Kalkal and Parmod Bhardwaj (2014) the industrialization through establishment of thermal power plant had significantly changed the land use/land cover pattern in rural areas, particularly in nearby areas (Jharli and its surroundings) of National Capital Region (NCR) of Delhi. They also observed that in 2004-05, the agricultural land in the study area was $45604110 \mathrm{~m}^{2}$ contributing 93.66 per cent of total area. In the year 201112 , the agricultural land in the study area was 31838980 $\mathrm{m}^{2}$ and occupied 65.40 percent of total area. So, agricultural land had decreased by $13765130 \mathrm{~m}^{2}$ areas recording a decline of 28.27 percent. The decrease of crop land results less production in agricultural sector which affects the socio-economic condition of the concerned area. Information about land use change is necessary to update land cover maps and for effective management www.ijeab.com and planning of the resources for sustainable development (Alphan, 2003). In this regard, Kolaghat block has been considered as the victim of losing crop lands due to fly ash emitting from Kolaghat thermal power plant.

The objectives of the study:

- To examine the temporal and spatial impact of coal -burned thermal power plant on crop coverage.

- To identify the effect of fly ash on land use pattern of Kolaghat block.

- To assess the change in arable land, net cultivated land, gross cultivated land, cropping intensity, net irrigated area and gross irrigated area of Kolaghat block where thermal power plant is situated.

- To suggest and recommend some improving measures in order to minimize the impact of fly ash coming out from the thermal power plant.

- To generate awareness on agricultural sustainability in the affected area of coal fired thermal power plant.

\section{MATERIALS AND METHODS}

The data were collected from field survey. The $4 \mathrm{~km}$ distance from Kolaghat was delineated through the survey by using soil survey method (Soil Survey Staff, 1999). Mouza map and block map were used to estimate the different area (Fig. 1). The cultivated areas under different crops were collected from field survey in 2011, 2013 and 2015. Information of total geographical area and agricultural land were collected from the office of Assistant Director of Agriculture, Kolaghat, Government of West Bengal, India. Net cultivated area indicates the actual area used for raising crops. Gross cultivated area was estimated by collecting the field data of cropped area throughout year.Net irrigated area was measured by the field data collected where irrigation facility was availed. Cropping intensity was estimated by the formula (total cultivated area throughout year / net cultivable area multiplied by 100).

\section{RESULTS AND DISCUSSION}

In the Kolaghat block where thermal power plant (KTPP) is situated, different crops are being cultivated throughout the year. Several crops have been losing their areas during (2011-2015) the study has been carried out. The crop coverage concerned with geographical area, arable land, net cultivable land, gross cultivated area, cropping intensity (CI), net and gross irrigated areas, nonagricultural land, crop wise area distribution etc. has been described for depicting the influence of fly ash coming 
out from KTPP in the adjacent areas $(4 \mathrm{~km})$ and the distant areas $(>4 \mathrm{~km})$ from KTPP.

\subsection{Effect of Fly ash on Spatial and temporal} changes of Crop Coverage:

Crop area of Kolaghat block is influenced by the Kolaghat thermal power plant. Different crops like rice, wheat, maize, mustard, sesame, jute, vegetables, flowers, pulses spices etc grow in the block. These crops are losing their area within the radius of $4 \mathrm{~km}$ from the centre of KTPP (Table -1). In 2011 within $4 \mathrm{~km}$ radius rice was cultivated in 1890 ha area whereas in 2013 that area was 1837ha and in 2015 it is 1798 ha. Rice is the staple food of the area. The land under rice cultivation has been significantly decreasing (-4.87\% in 2015 from 2011) in the adjacent area of KTPP due to the fly ash emitting from the power plant which is affecting the vegetative and reproductive growth of paddy. Fly ash also is changing the soil properties which hinder the nutrient availability of the plant (Singh, et al., 1995; Basu, et al., 2009). On the other hand, rice is gaining area $(0.22 \%$ in 2013$)$ beyond the $4 \mathrm{~km}$ radius from KTPP because of local demand and supporting price.

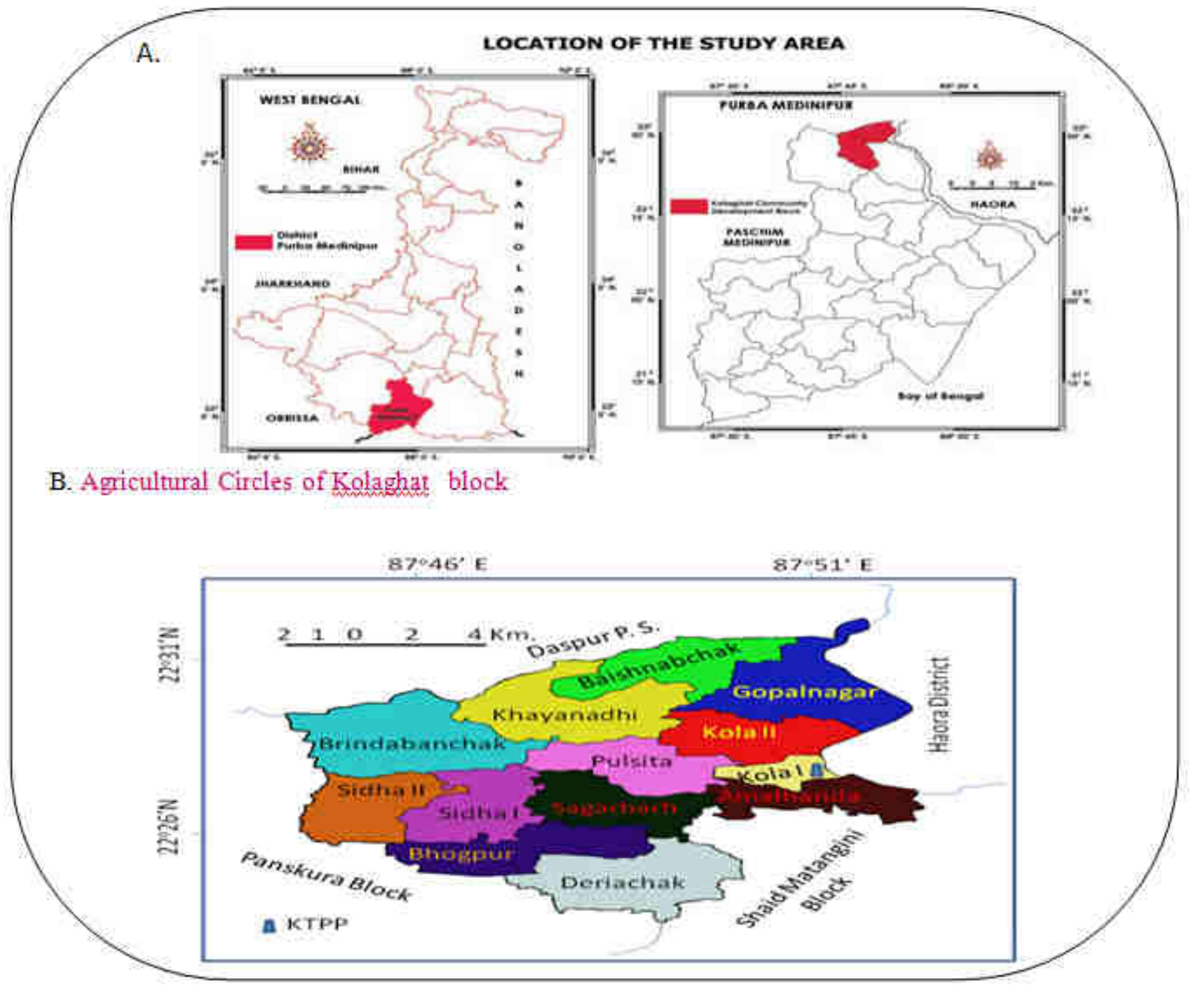

Fig.1: Location map of Kolaghat block in the district Purba Medinipur of West Bengal, India

Wheat and maize have been cultivated in lesser area ($67.6 \%$ and $-10 \%$ in 2015 from 2011) and are losing importance in the area within $4 \mathrm{~km}$ whereas their cultivation acreage outside the $4 \mathrm{~km}$ is increasing to some extent (6.25\% and $16.67 \%$ in 2015 over 2011). Major oil seed crops of the block are mustard and sesame. The two crops are facing the decreasing trend in area coverage ($29.1 \%$ and $-8.33 \%$ respectively from 2011 to 2015) though both are having good demand in the locality affected by fly ash (Adak, et al., 2016). The areas outside $4 \mathrm{~km}$ are supporting the growing of these two crops resulting in increase $(1.54 \%$ and $25 \%$ respectively from 2011 to 2015) of cultivated land. Vegetables, flowers, pulses and spices crops are losing the land area yearly. The arable areas under these crops in 2011 are vividly depicting the decreasing trend in 2015 whereas the 
situation is increasing trend beyond the $4 \mathrm{~km}$ from the power plant due to lesser impact of fly ash and cost of cultivation. Vegetables, flowers, pulses and spices crops have gained area $1.83 \%, 3.93 \%, 6.37 \%$ \& $46.53 \%$ respectively over the area in 2011 . It has been observed that total crop area in the surrounding land $(<4 \mathrm{~km})$ of KTPP is affected by the power plant which reflects the decrease in crop land( $-8.26 \%$ in 2015 from 2011) whereas in the rest $\operatorname{areas}(>4 \mathrm{~km}$ from KTPP) of Kolaghat block, the total crop coverage has increased by $1.7 \%$ over last four years (2011-2015).

\subsection{Impact of fly ash on cultivable land and cropping} intensity:

In the Kolaghat block, cultivable area is losing gradually over passage of time (Table 2, $3 \& 4$ ). Fly ashes usually have been shedding in considerable amount within the 4 $\mathrm{km}$ from the power plant (Adak, et al., 2016; Dasgupta, A. and Paul, S., 2011). At Kola-I,Kola-II, Gopalnagar. Pulsita, Amulhanda which are situated within the radius of $4 \mathrm{~km}$ from the Kolaghat thermal power plant, the percentage of cultivable land to the total geographical area have been found more decreasing trend than the circles i.e., Baishnabchak , Sagarbarh, Deriachak,
Bhogpur, Siddha-I, Siddha-II and Brindabanchak which are beyond $4 \mathrm{~km}$ of power plant. Kola-I has experienced the $79.53 \%, 77.86 \%$ and $76.86 \%$ arable land over total geographical area respectively in 2011, 2013 and 2015. At Kola-II the losing trend has become little bit higher (55.18\% in $2011,53.72 \%$ in 2013 \& $52.32 \%$ in 2015$)$ due to proximity of the location of dumping of the bottom ash of the thermal power plant. The area of Gopalnagar encompasses within 3-4 km of power plant. The farming land of Gopalnagar is also considerably losing by 2-3\% over the period of two years. The cultivable area of Khayanadhi (4-6Km) has no significant change due to location of outside of impact zone of flay ash. The circle Amulhanda is also suffering from losing arable land (2$3 \%$ by two years). The rest circles of Kolaghat block have not been influenced by the fly ash generated by the coalburned power plant. But the changes in farming land of these circles are results of low demand, high prices of farming inputs, less market prices of crops' produces etc. The gap of cultivable land between inside and outside of impact zone of fly ash is becoming wider $(9.63 \%$ in 2011 and $10.40 \%$ in 2015 ) with passage of time.

Table.1: Crop-wise land coverage within 4km and beyond it in the year 2011, 2013\& 2015 of Kolaghat block

\begin{tabular}{|c|c|c|c|c|c|c|c|c|c|c|}
\hline \multirow{3}{*}{$\begin{array}{l}\text { Name of } \\
\text { crops }\end{array}$} & \multicolumn{2}{|l|}{2011} & \multicolumn{4}{|l|}{2013} & \multicolumn{3}{|l|}{2015} & \multirow{3}{*}{$\begin{array}{l}\% \\
\text { Change }\end{array}$} \\
\hline & $<4 \mathbf{k m}$ & $>4 \mathrm{~km}$ & $<4 \mathrm{~km}$ & \multirow{2}{*}{$\begin{array}{l}\% \\
\text { Change }\end{array}$} & $>4 \mathrm{~km}$ & \multirow{2}{*}{$\begin{array}{l}\% \\
\text { Change }\end{array}$} & $<4 \mathrm{~km}$ & \multirow{2}{*}{$\begin{array}{l}\% \\
\text { Change }\end{array}$} & \multirow{2}{*}{$\begin{array}{l}>4 \mathbf{k m} \\
\operatorname{Area}(\mathrm{ha})\end{array}$} & \\
\hline & Area(ha) & Area(ha) & Area(ha) & & Area(ha) & & Area(ha) & & & \\
\hline Rice & 1890 & 5391 & 1837 & -2.804 & 5403 & 0.22 & 1798 & -4.87 & 5386 & -0.09 \\
\hline Wheat & 3.7 & 8 & 2.1 & -43.24 & 7 & -12.5 & 1.2 & -67.6 & 8.5 & 6.25 \\
\hline Maize & 7 & 12 & 5.4 & -22.86 & 11 & -8.33 & 6.3 & -10 & 14 & 16.67 \\
\hline Mustard & 55 & 130 & 45 & -18.18 & 125 & -3.85 & 39 & -29.1 & 132 & 1.54 \\
\hline Sesame & 6 & 28 & 4.8 & -20 & 30 & 7.14 & 5.5 & -8.33 & 35 & 25 \\
\hline Jute & 5 & 71 & 4.2 & -16 & 73 & 2.82 & 4.5 & -10 & 70 & -1.41 \\
\hline Vegetables & 445 & 1312 & 392 & -11.91 & 1350 & 2.9 & 379 & -14.8 & 1336 & 1.83 \\
\hline Flowers & 806 & 1171 & 764 & -5.21 & 1204 & 2.82 & 741 & -8.06 & 1217 & 3.93 \\
\hline Pulses & 105 & 377 & 92 & -12.38 & 339 & -10.1 & 71 & -32.4 & 401 & 6.37 \\
\hline Spices & 21 & 101 & 17 & -19.1 & 123 & 21.8 & 22 & 4.76 & 148 & 46.53 \\
\hline Total & 3343.7 & 8601 & 3163.5 & -5.389 & 8665 & 0.74 & 3067.5 & -8.26 & 8747.5 & 1.7 \\
\hline
\end{tabular}

Cropping intensity (CI) is estimated from gross cultivated area throughout the year to net cultivated area multiplied by 100 . The overall CIs of the block are $190.2 \%$, $185.3 \%$ and $177.9 \%$ in the years $2011,2013 \& 2015$ respectively. The notable fall $(181.3 \%$ to $166.8 \%)$ in CI has been observed during last four years (2011-2015) in the circles within $4 \mathrm{~km}$ from the KTPP whereas it has shifted from $195.15 \%$ to $183.6 \%$ beyond $4 \mathrm{~km}$. This is due to adverse impact of fly ash coming out of power plant (Adak, et al., 2016; Dasgupta, A. and Paul, S., 2011). The rest circles are losing the very little CI due to lesser margin in profit and high cost of cultivation. Maximum CI has been found in Siddha-II (222.69\% in $2011,210.7 \%$ in $2013 \& 200.22 \%$ in 2015) in consequence of the fertile land, irrigation facility, community farming etc. 
Table.2: Circle-wise Geographical Area, Cultivable Area, Cultivated Area \& Irrigated Area- 2011

\begin{tabular}{|c|c|c|c|c|c|c|c|c|c|c|}
\hline 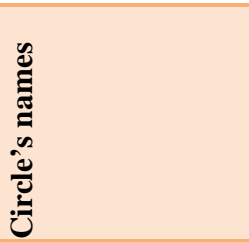 & 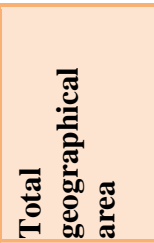 & 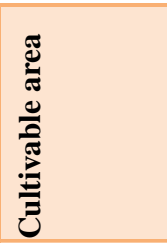 & 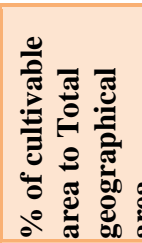 & 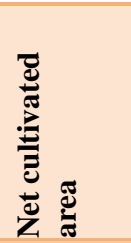 & 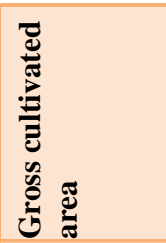 & 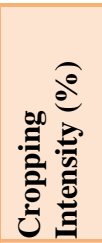 & 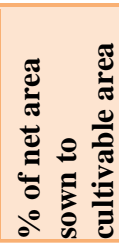 & 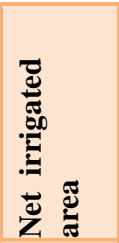 & 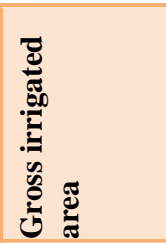 & 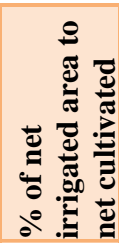 \\
\hline Kola-I & 405.428 & 322.457 & 79.53 & 287.165 & 517.542 & 180.2 & 89.06 & 251.43 & 498.251 & 87.55 \\
\hline Kola-II & 1151.541 & 635.463 & 55.18 & 543.241 & 1012.341 & 186.4 & 85.49 & 516.13 & 927.582 & 95.01 \\
\hline Gopalnagar & 1492.578 & 938.046 & 62.85 & 798.735 & 1427.478 & 178.7 & 85.15 & 759.47 & 1254.354 & 95.08 \\
\hline Sagarbarh & 1040.979 & 908.055 & 87.23 & 813.916 & 1478.925 & 181.7 & 89.63 & 784.32 & 1264.254 & 96.36 \\
\hline Amulhanda & 759.752 & 378.45 & 49.81 & 327.825 & 685.942 & 209.2 & 86.62 & 310.27 & 547.523 & 94.64 \\
\hline Pulsita & 1118.15 & 854.69 & 76.44 & 687.498 & 1147.143 & 166.9 & 80.44 & 640.78 & 1075.951 & 93.21 \\
\hline $\begin{array}{l}\text { Sub-total } \\
(<4 \mathrm{~km})\end{array}$ & 5968.428 & 4037.161 & 67.64 & 3458.4 & 6269.371 & 181.3 & 85.66 & 3262 & 5567.915 & 94.33 \\
\hline Baishnabchak & 1245.124 & 829.854 & 66.65 & 726.463 & 1398.415 & 192.5 & 87.54 & 708.15 & 1191.589 & 97.48 \\
\hline Khayanadhi & 1719.377 & 1333.858 & 77.58 & 1109.18 & 1991.957 & 179.6 & 83.16 & 1091.3 & 1737.892 & 98.39 \\
\hline Deriachak & 1411.474 & 1150.684 & 81.52 & 1017.82 & 1896.358 & 186.3 & 88.45 & 923.45 & 1686.584 & 90.73 \\
\hline Bhogpur & 1122.369 & 764.243 & 68.09 & 658.925 & 1109.546 & 168.4 & 86.22 & 511.93 & 1004.317 & 77.69 \\
\hline Siddha-I & 1052.795 & 915.264 & 86.94 & 843.162 & 1782.421 & 211.4 & 92.12 & 819.31 & 1597.369 & 97.17 \\
\hline Siddha-II & 1057.41 & 882.679 & 83.48 & 735.289 & 1637.427 & 222.7 & 83.3 & 721.98 & 1478.147 & 98.19 \\
\hline Brindabanchak & 1903.533 & 1378.625 & 72.42 & 1231.27 & 2518.664 & 204.6 & 89.31 & 1176.4 & 2299.358 & 95.55 \\
\hline $\begin{array}{l}\text { Sub-total } \\
(>4 \mathrm{~km})\end{array}$ & 9512.082 & 7255.207 & 76.27 & 6322.1 & 12334.79 & 195.1 & 87.14 & 5953 & 10995.256 & 94.15 \\
\hline Grand Total & 15480.51 & 11292.368 & 72.95 & 9780.49 & 18604.159 & 190.2 & 86.61 & 9214.9 & 16563.171 & 94.22 \\
\hline
\end{tabular}

Table.3. Circle-wise Geographical Area, Cultivable Area, Cultivated Area \& Irrigated Area- 2013

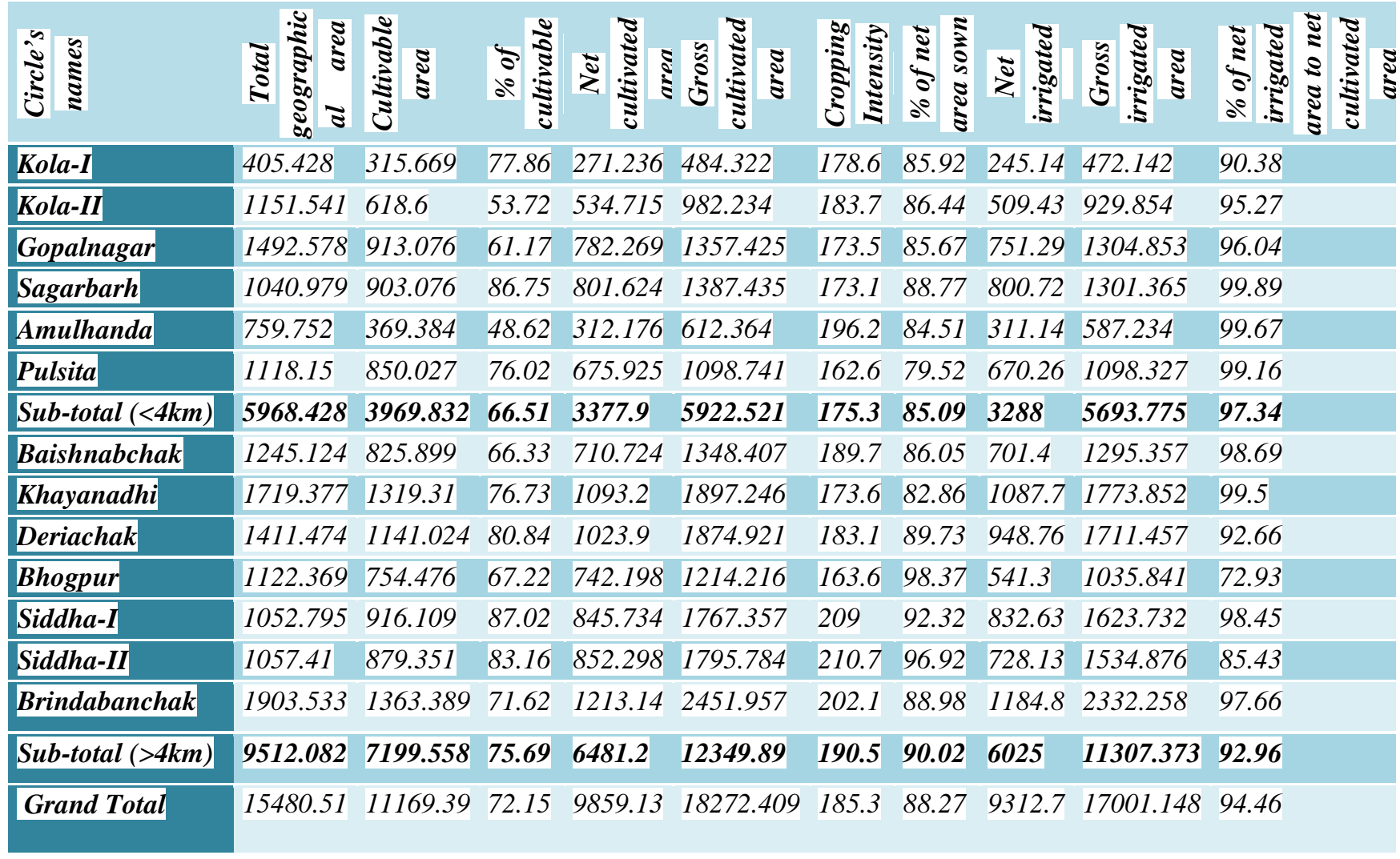


The decrease in gross cultivated land has been experienced in the areas within the distance of $4 \mathrm{~km}$ from KTPP. Fly ash is affecting the agriculture of these circles. Gross irrigated area has increased to some extent. Percentage of irrigated area has got enhanced due to uses of water lifting pumps, water carrying pipes procured from government scheme of farm mechanization or personally purchased. All the circles of the Kolaghat block are having the irrigation facility in more than $90 \%$ of the cultivated land except Bhogpur (76.6\% in 2015) and Siddha-II $(87.88 \%$ in2015) which are situated in $>4 \mathrm{~km}$.

Table.4. Circle-wise Geographical Area, Cultivable Area, Cultivated Area \& Irrigated Area- 2015

\begin{tabular}{|c|c|c|c|c|c|c|c|c|c|c|c|}
\hline 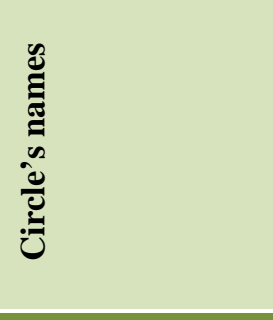 & 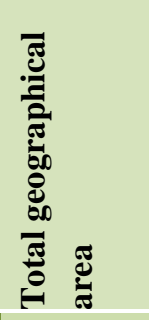 & 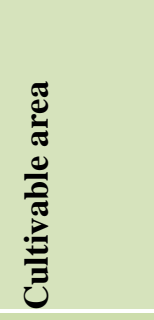 & 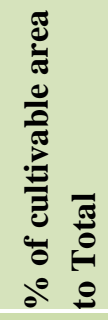 & 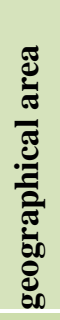 & 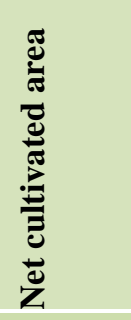 & 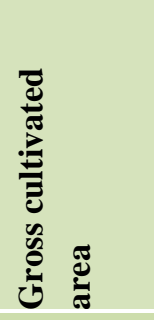 & 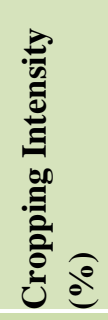 & 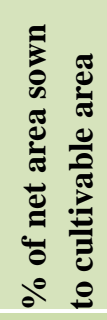 & 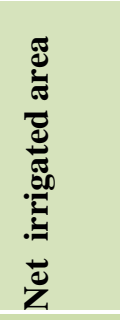 & 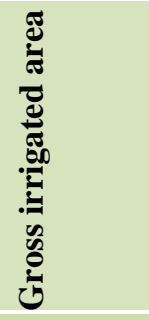 & 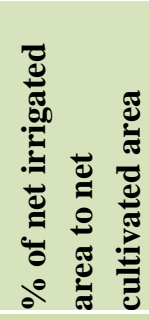 \\
\hline Kola-I & 405.428 & 311.617 & 76.86 & & 253.745 & 413.254 & 162.9 & 81.43 & 238.44 & 395.214 & 93.97 \\
\hline Kola-II & 1151.541 & 602.522 & 52.32 & & 521.263 & 907.365 & 174.1 & 86.51 & 501.29 & 885.367 & 96.17 \\
\hline Gopalnagar & 1492.578 & 900.105 & 60.31 & & 770.149 & 1280.341 & 166.2 & 85.56 & 756.13 & 1207.451 & 98.18 \\
\hline Sagarbarh & 1040.979 & 898.105 & 86.28 & & 785.764 & 1347.475 & 171.5 & 87.49 & 706.74 & 1285.214 & 89.94 \\
\hline Amulhanda & 759.752 & 359.674 & 47.34 & & 321.536 & 558.347 & 173.6 & 89.4 & 316.63 & 513.564 & 98.47 \\
\hline Pulsita & 1118.15 & 838.37 & 74.98 & & 671.239 & 1037.367 & 154.5 & 80.06 & 665.24 & 1002.372 & 99.11 \\
\hline Sub-total $(<4 \mathrm{~km})$ & 5968.428 & 3910.393 & 65.52 & & 3323.7 & 5544.149 & 166.8 & 85 & 3184 & 5289.182 & 95.81 \\
\hline Baishnabchak & 1245.124 & 810.079 & 65.06 & & 705.625 & 1291.478 & 183 & 87.11 & 700.21 & 1217.258 & 99.23 \\
\hline Khayanadhi & 1719.377 & 1312.036 & 76.31 & & 1132.43 & 1897.189 & 167.5 & 86.31 & 1083.9 & 1726.964 & 95.72 \\
\hline Deriachak & 1411.474 & 1136.194 & 80.5 & & 1053.46 & 1783.152 & 169.3 & 92.72 & 962.78 & 1702.861 & 91.39 \\
\hline Bhogpur & 1122.369 & 747.965 & 66.64 & & 726.235 & 1287.068 & 177.2 & 97.09 & 556.3 & 1128.345 & 76.6 \\
\hline Siddha-I & 1052.795 & 910.353 & 86.47 & & 851.924 & 1684.254 & 197.7 & 93.58 & 840.73 & 1614.863 & 98.69 \\
\hline Siddha-II & 1057.41 & 874.359 & 82.69 & & 855.839 & 1713.546 & 200.2 & 97.88 & 752.13 & 1587.139 & 87.88 \\
\hline Brindabanchak & 1903.533 & 1354.295 & 71.15 & & 1224.2 & 2368.412 & 193.5 & 90.39 & 1196.3 & 2346.275 & 97.72 \\
\hline Sub-total $(>4 \mathrm{~km})$ & 9512.082 & 7145.281 & 75.12 & & 6549.7 & 12025.1 & 183.6 & 91.66 & 6092 & $\begin{array}{l}11323.70 \\
5\end{array}$ & 93.02 \\
\hline Grand Total & 15480.51 & $\begin{array}{l}11055.67 \\
4\end{array}$ & 71.42 & & 9873.4 & $\begin{array}{l}17569.24 \\
8\end{array}$ & 177.9 & 89.31 & 9276.8 & $\begin{array}{l}16612.88 \\
7\end{array}$ & 93.96 \\
\hline
\end{tabular}

\subsection{Effect of fly ash on Land use pattern change:}

The surrounding areas $(<4 \mathrm{~km})$ of Kolaghat thermal power plant significantly and gradually have been turning to non-agricultural land after installation of Kolaghat thermal power plant (Table 5). Kola-I had the arable land of 82.971 hectare in 2011 and in 2015 it has been observed that $3.36 \%$ has lost. The farming area of Kola-II also has been reduced by $5.18 \%$ in four years (20112015). But the nature of change is fluctuating. The farming community turns the no crops' lands to cultivated land when they perceive the profitable return from cultivation and also are being encouraged by the several schemes of agricultural department or NGOs with funds www.ijeab.com support or inputs supply free of cost. Usually the trends depict that the agricultural land has been left more unseeded in the adjacent areas of Kolaghat thermal power plant. The circles within $4 \mathrm{~km}$ from power plant i.e. KolaI, Kola-II, Gopalnagar Pulsita, Amulhanda have been changing the pattern of land use by $-1.096 \%$ to $-5.18 \%$ in 2015 from 2011. Land-cover modification is frequently caused by changes in the management of agricultural land use (Lambin, et al., 2000). Agricultural land in the alarming zones of fly ash is being turned to fallow area, habitation \& transport of increasing population or converted to water bodies in the Kolaghat block. 
Table.5: Circle -wise conversion agricultural land to non-agricultural land \& change percentage year-wise

\begin{tabular}{|c|c|c|c|c|c|c|}
\hline \multirow{2}{*}{$\begin{array}{l}\text { Circle's name } \\
\text { (hectare) }\end{array}$} & \multirow[t]{2}{*}{ Land area } & \multirow{2}{*}{ Area(ha) } & \multicolumn{2}{|c|}{2013} & \multicolumn{2}{|c|}{2015} \\
\hline & & & & \%change & Area(ha) & \%change \\
\hline \multirow{2}{*}{$\begin{array}{l}\text { Kola-I } \\
(\mathbf{4 0 5 . 4 2 8 )}\end{array}$} & Non- agricultural & 82.971 & 89.759 & 8.181 & 93.811 & 13.065 \\
\hline & Agricultural & 322.457 & 315.669 & -2.105 & 311.617 & -3.362 \\
\hline \multirow{2}{*}{$\begin{array}{l}\text { Kola-II } \\
\text { (1151.541) }\end{array}$} & Non-agricultural & 516.078 & 532.941 & 3.268 & 549.019 & 6.3829 \\
\hline & Agricultural & 635.463 & 618.6 & -2.654 & 602.522 & -5.184 \\
\hline \multirow{2}{*}{$\begin{array}{l}\text { Gopalnagar } \\
\text { (1492.578) }\end{array}$} & Non-agricultural & 554.532 & 579.502 & 4.503 & 592.473 & 6.842 \\
\hline & Agricultural & 938.046 & 913.076 & -2.662 & 900.105 & -4.045 \\
\hline \multirow{2}{*}{$\begin{array}{l}\text { Pulsita } \\
(1118.15)\end{array}$} & Non-agricultural & 263.46 & 268.123 & 1.77 & 279.78 & 6.1945 \\
\hline & Agricultural & 854.69 & 850.027 & -0.546 & 838.37 & -1.909 \\
\hline \multirow{2}{*}{$\begin{array}{l}\text { Sagarbarh } \\
(1040.979)\end{array}$} & Non-agricultural & 132.924 & 137.903 & 3.746 & 142.874 & 7.4855 \\
\hline & Agricultural & 908.055 & 903.076 & -0.548 & 898.105 & -1.096 \\
\hline \multirow{2}{*}{$\begin{array}{r}\text { Amalhanda } \\
(\mathbf{7 5 9 . 7 5 2 )}\end{array}$} & Non-agricultural & 381.302 & 390.368 & 2.378 & 400.078 & 4.9242 \\
\hline & Agricultural & 378.45 & 369.384 & -2.396 & 359.674 & -4.961 \\
\hline \multirow{2}{*}{$\begin{array}{l}\text { Sub Total }(<4 \mathrm{~km}) \\
(5968.428)\end{array}$} & Non-agricultural & 2217.83 & 2289.617 & 3.237 & 2357.469 & 6.2962 \\
\hline & Agricultural & 4037.161 & 3969.832 & -1.668 & 3910.393 & -3.14 \\
\hline \multirow{2}{*}{$\begin{array}{l}\text { Baishnabchak } \\
\text { (1245.124) }\end{array}$} & Non-agricultural & 415.27 & 419.225 & 0.952 & 435.045 & 4.762 \\
\hline & Agricultural & 829.854 & 825.899 & -0.477 & 810.079 & -2.383 \\
\hline \multirow{2}{*}{$\begin{array}{l}\text { Khanyadihi } \\
\text { (1719.377) }\end{array}$} & Non-agricultural & 385.519 & 400.067 & 3.774 & 407.341 & 5.6604 \\
\hline & Agricultural & 1333.858 & 1319.31 & -1.091 & 1312.036 & -1.636 \\
\hline \multirow{2}{*}{$\begin{array}{l}\text { Deriachak } \\
\text { (1411.474) }\end{array}$} & Non-agricultural & 260.79 & 270.45 & 3.704 & 275.28 & 5.5562 \\
\hline & Agricultural & 1150.684 & 1141.024 & -0.84 & 1136.194 & -1.259 \\
\hline \multirow{2}{*}{$\begin{array}{l}\text { Bhogpur } \\
(\mathbf{1 1 2 2 . 3 6 9 )}\end{array}$} & Non-agricultural & 358.126 & 367.893 & 2.727 & 374.404 & 4.5453 \\
\hline & Agricultural & 764.243 & 754.476 & -1.278 & 747.965 & -2.13 \\
\hline \multirow{2}{*}{$\begin{array}{l}\text { Siddha-I } \\
\text { (1052.795) }\end{array}$} & Non-agricultural & 137.531 & 136.686 & -0.614 & 142.442 & 3.5708 \\
\hline & Agricultural & 915.264 & 916.109 & 0.092 & 910.353 & -0.537 \\
\hline \multirow{2}{*}{$\begin{array}{l}\text { Siddha-II } \\
\text { (1057.41) }\end{array}$} & Non-agricultural & 174.731 & 178.059 & 1.905 & 183.051 & 4.7616 \\
\hline & Agricultural & 882.679 & 879.351 & -0.377 & 874.359 & -0.943 \\
\hline \multirow{2}{*}{$\begin{array}{l}\text { Brindabanchak } \\
\text { (1903.533) }\end{array}$} & Non-agricultural & 524.908 & 540.144 & 2.903 & 549.238 & 4.6351 \\
\hline & Agricultural & 1378.625 & 1363.389 & -1.105 & 1354.295 & -1.765 \\
\hline \multirow{2}{*}{$\begin{array}{l}\text { Sub Total(>4km) } \\
(9512.082)\end{array}$} & Non-agricultural & 2256.875 & 2312.524 & 2.466 & 1117.666 & -50.48 \\
\hline & Agricultural & 7255.207 & 7199.558 & -0.767 & 7145.281 & -1.515 \\
\hline \multirow{2}{*}{$\begin{array}{l}\text { Total area } \\
(\mathbf{1 5 4 8 0 . 5 1 )}\end{array}$} & Non-agricultural & 4188.142 & 4311.12 & 2.936 & 4424.836 & 5.6515 \\
\hline & Agricultural & 11292.368 & 11169.39 & -1.089 & 11055.674 & -2.141 \\
\hline
\end{tabular}

The land use types have got little bit of decrease $(0.943 \%$ to $2.383 \%$ over last four years $)$ in the circles which are outside of $4 \mathrm{~km}$ distant from KTPP due to habitation, road construction, non profitable agriculture etc (Fig.2). It leads to potential threat to agricultural production due to the constant loss of arable land (Masek et al., 2000 and $\mathrm{Ji}$, et al., 2001). Maximum decrease $(5.18 \%)$ of land use type has been observed in Kola-II. It is ascertained that fly ash is affecting the land use pattern of the surrounding areas of Kolaghat thermal power plant. As a result the agricultural land has lost $3.14 \%(<4 \mathrm{~km})$ and $1.515 \%(>4 \mathrm{~km})$ reflecting nearly double drip. Rate of

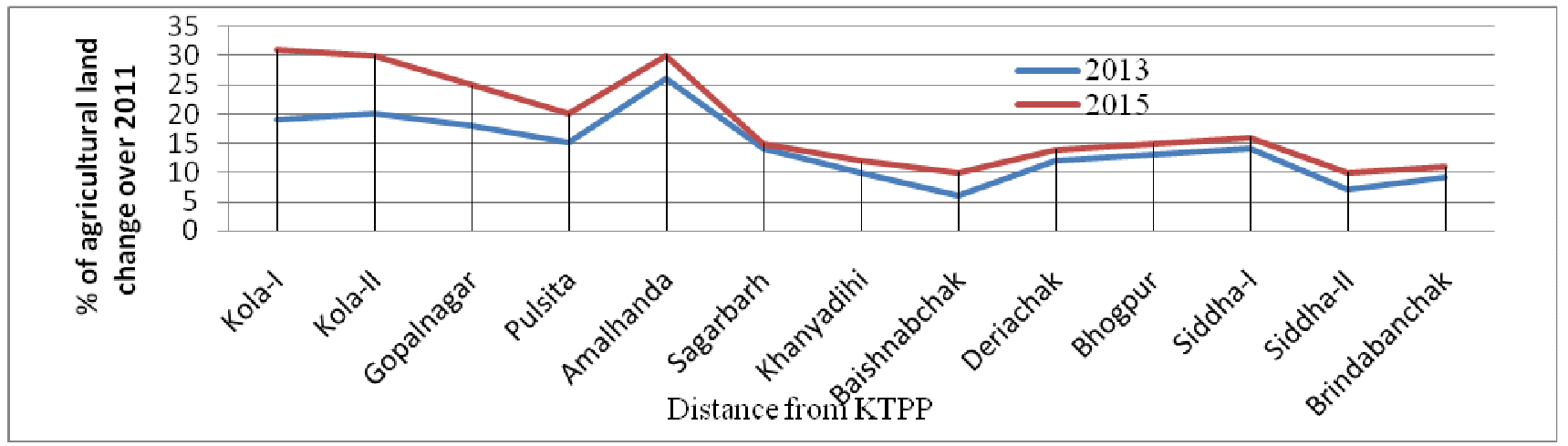

Fig.2: Decrease in agricultural land with passage of time (2011-2015) and distance (km) from KTPP 
transformation (13.06\% over last four years) to Nonarable land has been found highest in Kola-I which is very closer to the power plant and ash ponds are situated in this circle. During transportation to the ponds, ashes start spreading around the area of travelling of vehicles. Overall land use pattern of Kolaghat block has changed from arable to non-agricultural land by $2.141 \%$ in four years (2011-2015).

\section{Recommendation:}

The Kolaghat Thermal power plant authority should adopt the emerging technology to minimize the emission of fly ash from the chimneys. During disposal and transportation of bottom ash, care should be taken in order to reduce the spreading of ash on the ways. The KTPP authority should arrange the plantation of suitable trees in the surroundings and encourage the planting programme on regular basis. They may conduct impact assessment of fly ash at the adjacent areas in reasonable interval. On the basis of evaluated impact of fly ash, site specific cropping pattern, crop suitability, alternative land use pattern, potential crop selectivity etc should be adopted. The proper and sustainable agricultural practices would be exercised as per localized need based approaches. Organic farming system and precision agriculture can be run to abate the effect of the alkaline nature of fly ash. Detailed evaluation of land capability, site -specific suitability, land irrigability and crop selectivity may be conducted to find out the best possible uses of land in the affected area of KTPP. The evaluation of crop suitability around the KTPP (conducted by Adak et al., 2016) can be followed to utilize the land properly in order to sustain the agriculture in the rural areas around the KTPP.

\section{CONCLUSION}

Fly ash emitting from Kolaghat thermal power plant considerably has been affecting the surrounding area $(<4 \mathrm{~km})$ under different crops. Conversion of agricultural land to non - arable is alarming for sustainable agriculture. Cropping intensity which indicates the yearly repetition of crop farming upon net cultivable land has been dropping gradually. The present study reveals that the fly ash has been reducing the crop growing potentiality of the adjacent areas. The rest circles $(>4 \mathrm{~km})$ of Kolaghat block have no or very little bit of impact of fly ash or gradually effect has been deceasing with increase of distance from KTPP. Site- specific resources and problem management as well as precision farming should be adopted for agricultural sustainability and improvement of socio-economic condition of the fly ash affected area.

\section{ACKNOWLEDGEMENT}

We are very grateful to the Office of Assistant Director of Agriculture, Kolaghat, Government of West Bengal Bidhan Chandra Krishi Viswavidyalaya, Mohonpur, West Bengal; National Institute of Technology, Durgapur; Agricultural Training Centre, Ramakrishna Mission Asharama, Narendrapur, Kolkata-700103 for providing valuable different assistance for conducting our research work.

\section{REFERENCES}

[1] Adak, S., Adhikari, K. and Brahmachari, K., "GISbased Evaluation of Crop Suitability for Agricultural Sustainability around Kolaghat Thermal Power plant, India," Journal of Environmental Biology, vol.37 (5) pp. 905-912. 2016.

[2] Alphan, H., "Land use changes and urbanization in Adana, Turkey, Land degradation and Development," vol. 14, pp.575-586, 2003.

[3] Avirneni, S. and Bandlamudi, D., "Environmental Impact of Thermal Power Plant in India and Its Mitigation Measure," International Journal of Modern Engineering Research, vol.3 (2), pp.10261031, 2013.

[4] Basu, M., Pande, M., Bhadoria, P.B.S. and Mahaptra, S.C., "Potential fly-ash utilization in agriculture: A global review," Progress in Natural Science, vol. 19(10), pp.1173-1186, 2009.

[5] Chitade A. Z. and S. K. Katyar, "Impact Analysis of open Cast Coal Mines on Land use / Land Cover using remote Sensing and GIS Technique: A Case study," International Journal of Engineering Science and Technology, Vol. 2 (12), pp.7171-7176, 2010.

[6] Dasgupta, A. and Paul, S., "Fly ash and its impact on land: a case study of Kolaghat thermal power plant, Purba Medinipur, West Bengal," Indian Journal of Spatial Science, vol. 11(2), Article 2,2011.

[7] Dudhapachare, Y.Y., "Cumulitive Agriculture Impact Assessment of the Upcoming Thermal Power Plants in Chandrapur, District of Maharashtra," Review of Research, vol. 1(V), pp.1-4, 2012.

[8] Garg, J. K., "Impact of Mining Activities and Super Thermal Power Stations on Environment," Space Applications Centre (SAC) Ambawadi Vistar P.O., Ahmedabad-380 015, Gujarat, 1990.

[9] Ji, C. Y., Liu, Q. H., Sun, D. F., Wang, S., Lin, P., \& Li, X. W., "Monitoring urban expansion with remote sensing in China," International Journal of Remote Sensing, vol. 22, pp.1441-1455, 2001. 
[10]Kumar, S., Katoria, D. and Sehgal, D., "Environment Impact Assessment of Thermal Power Plant for Sustainable Development," International Journal of Environmental Engineering and Management, vol. 4(6), pp.567-572, 2013.

[11]Lambin, E.F., Rounsevell, M.D.A. and Geist, H.J., "Are agricultural land-use models able to predict changes in land-use intensity?" Agriculture, Ecosystems and Environment, vol. 82, pp. 321-331, 2000.

[12] Joshi, V. U. and Nagare,V. , "Land Use Change Detection along the Pravara River Basin in Maharashtra, Using Remote Sensing and GIS Techniques," AGD Landscape and Environment, vol.3(2), pp.71-86, 2009.

[13] Masek, J.G., Lindsay, F.E. and Goward, S.N., "Dynamics of Urban Growth in Washington D.C. Metropolitan Area 1973-1996 from Landsat Observations," International Journal of Remote Sensing, vol. 21(18), pp.3473-3486, 2000.

[14]National Environmental Engineering Research Institute, "Summary report of the study on PostClearance Environmental Impacts and Cost-benefit Analysis of Power Generation in India" February, 2006.

[15] Salesh Kalka, S. and Bhardwa, P., "Policy induced land use/land cover change: a case study of industrial development at Jharli and its surroundings in Haryana (India)," International Journal of Geomatics and Geosciences, vol. 5(2), pp.275-283, 2014.

[16] Shamshad, A., Fulekar M.H. and Bhawana, P., "Impact of Coal Based Thermal Power Plant on Environment and its Mitigation Measure," International Research Journal of Environment Sciences, vol. 1(4), pp.60-64, 2012.

[17] Singh, J., Agrawal, M., and Narayan D., "Changes in soil characteristics around coal-fired power plant," Environment International, vol. 21(1), pp.93102, 1995.

[18] Soil Survey Staff, "Soil taxonomy: A basic system of soil classification for making and interpreting soil surveys," 2nd edition, Natural Resources Conservation Service, U.S. Department of Agriculture Handbook 436, 1999.

[19]"All India Installed Capacity of Utility Power Stations" (PDF). Retrieved 9 September 2016 (accessed on 15/09/2016).

[20] www.moef.nic.in/sites/default/files/WetlandsSummaries.pdf (accessed on 15/09/2016). 